\title{
STRONTIUM ISOTOPE GEOCHEMISTRY OF LATE CRETACEOUS GRANODIORITES, JAMAICA AND HAITI, GREATER ANTILLES
}

\author{
L.M. JONES ${ }^{1}$, RAYMOND L. WALKER ${ }^{2}$, S.E. KESLER ${ }^{3}$ and JOHN F. LEWIS ${ }^{4}$ \\ ${ }^{1}$ Research and Development Department, Continental Oil Company, Ponca City, OK 74601 (U.S.A.) \\ 2 Oak Ridge National Laboratory, Oak Ridge, TN 37830 (U.S.A) \\ ${ }^{3}$ Department of Geology, University of Michigan, Ann Arbor, MI 48109 (U.S.A.) \\ ${ }^{4}$ Department of Geology, George Washington University, Washington, DC 20052 (U.S.A.)
}

Received December 21, 1978

\begin{abstract}
Initial ${ }^{87} \mathrm{Sr} /{ }^{86} \mathrm{Sr}$ ratios have been determined for a representative suite of Upper Cretaceous granodiorites and associated rocks from the Above Rocks composite stock in central Jamaica and the Terre-Neuve pluton in northwestern Haiti. The average initial ${ }^{87} \mathrm{Sr} /{ }^{86} \mathrm{Sr}$ ratio for severn samples of the Terre-Neuve intrusion is 0.7036 , with a range of $0.7026-0.7047$. For two samples of the Above Rocks the initial ratios are 0.7033 and 0.7034 . A third sample from this intrusive has an initial ratio of 0.7084 , which is tenatively attributed to contamination. The initial ${ }^{87} \mathrm{Sr} /{ }^{86} \mathrm{Sr}$ ratios indicate that neither ancient sialic crust nor sediments carried down a Benioff zone can be the primary source of the granodioritic magma. $\mathrm{K} / \mathrm{Rb}$ ratios for these rocks range from 178 to 247 , which are much lower than the average values $(\geqslant 1000)$ for tholeiitic basalts. It is concluded that the magmas originated primarily by melting of downthrust oceanic crust or adjacent mantle material.
\end{abstract}

\section{Introduction}

Intrusive rocks form an important part of the crust of the Greater Antilles and the Nicaraguan Rise [1]. Regional mapping and petrologic studies [2-4] have confirmed the early generalization [5] that most of the intrusive rocks in the Greater and Lesser Antilles are of quartz-dioritic (tonalite) composition. A group of Late Cretaceous granodioritic complexes, presently known to include the Above Rocks (Jamaica), the Terre-Neuve (Haiti) and the Utuado (Puerto Rico) stocks, provide a striking exception to this generalization and must be considered to be significant features in any scheme for the tectonic or petrologic evolution of the Greater Antilles. The chemical similarity of these three intrusions is of greater significance because of their close similarity in ages. Radiometric dates, mainly $\mathrm{K}-\mathrm{Ar}$, for the intrusions range from 62 to $66 \mathrm{m.y}$. [6-10].

These granodiorites consist of early-crystallized plagioclase, hornblende, and biotite with later interstitial sodic plagioclase, K-feldspar, and quartz.
Chemical analyses of samples from these intrusions $[9,11-13]$ clearly distinguishes them from island arc tonalites. Major elements show a typical calc-alkaline trend, but the rocks are decidedly higher in $\mathrm{K}_{2} \mathrm{O}$ and lower in $\mathrm{SiO}_{2}$ compared with the other quartz-dioritic and tonalitic plutonic complexes in the Antilles.

Donnelly et al. [11] distinguished two chemically distinct groups in the eastern West Indies: (1) an older "chemically primitive" pre-Middle Cretaceous group, mainly spilites and keratophyres, from the Virgin Islands, and (2) a "chemically more evolved" group dominant during the Middle Cretaceous to Recent. The latter group included the common basalts, andesites, and dacites of the Lesser and Greater Antilles as well as the plutonic rocks discussed here.

Since the early work of Faure and Hurley [14], the isotopic composition of strontium, conveniently expressed as the ${ }^{87} \mathrm{Sr} /{ }^{86} \mathrm{Sr}$ ratio, has been found to be a useful parameter in the understanding of the origin of igneous rocks and can provide information about the geologic processes that have affected their chemi- 


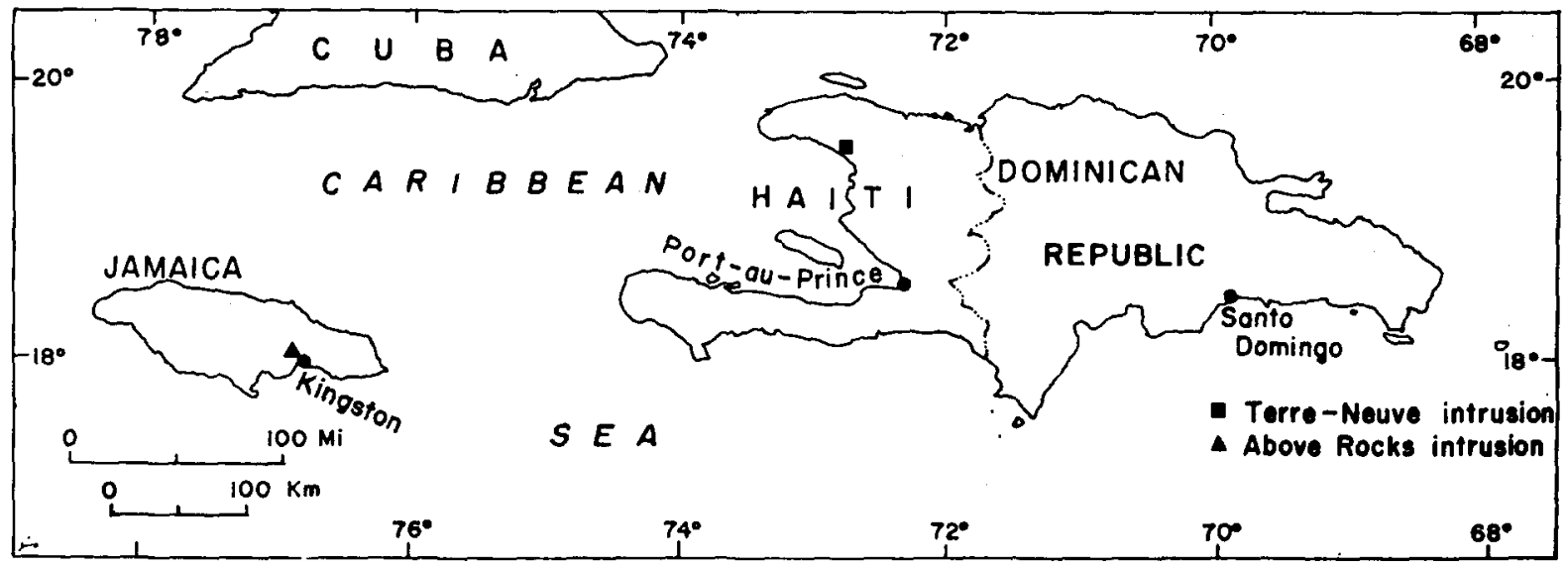

Fig. 1. Map of the western part of the Greater Antilles, showing the location of the Terre-Neuve intrusion in Haiti and the Above Rocks intrusion in Jamaica.

cal composition. It has become increasingly clear that the isotopic composition of strontium in igneous rock of island arcs has not evolved through a single stage process from a primordial source but probably involves the sum of a number of processes. Multistage processes for the evolution of the isotopic composition of both strontium and lead have been proposed during the past few years (e.g. [15-18]).

Most of the measurements of the isotope composition of strontium in the Caribbean have been made on volcanic rocks from the Lesser Antilles and from Puerto Rico and the Virgin Islands in the Greater Antilles. With few exceptions, most of the reported initial ${ }^{87} \mathrm{Sr} /{ }^{86} \mathrm{Sr}$ ratios for the Lesser Antilles lie in the range $0.703-0.705[11,19-21]$, i.e., values similar to those generally found for volcanic rocks in other island arc provinces.

We are reporting the isotopic composition of strontium in representative samples from the highpotassium granodioritic intrusives. Seven samples from the Terre-Neuve stock in Haiti and three samples from the Above Rocks intrusion, Jamaica, were analyzed. The location of the intrusions are shown in Fig. 1.

\section{Analytical methods}

The strontium was isolated from the whole-rock samples using $\mathrm{HF}-\mathrm{HNO}_{3}-\mathrm{H}_{2} \mathrm{SO}_{4}$ dissolution and cation-exchange chromatography in a $\mathrm{HCl}$ medium with ${ }^{89} \mathrm{Sr}$ tracer. The ${ }^{87} \mathrm{Sr} /{ }^{86} \mathrm{Sr}$ ratios were determined in a two-stage, 12 -inch radius, $90^{\circ}$-deflection solid-source mass spectrometer located at the Oak Ridge National Laboratory. The instrumentation has been described by Cameron et al. [22]. Results of the isotopic analyses are in Table 1.

The rubidium and strontium concentrations were determined (Table 1) in duplicate by X-ray fluorescence, using a Philips Model PW-1410 X-ray spectrometer, with $\mathrm{LiF}(220)$ analyzing crystal, scintillation counter, and molybdenum target tube. Matrix corrections were made by monitoring the $\mathrm{MoK}_{\alpha}$ peak.

\section{Discussion of the results}

The present-day and initial ${ }^{87} \mathrm{Sr} /{ }^{86} \mathrm{Sr}$ ratios for the suites of samples from the Above Rocks and TerreNeuve stocks show remarkably low values (Table 1). Initial ${ }^{87} \mathrm{Sr} /{ }^{86} \mathrm{Sr}$ ratios for the seven samples from the Terre-Neuve suite range from 0.7026 to 0.7047 and average 0.7036 . Two samples from the Above Rocks pluton are 0.7034 and 0.7033 and are indistinguishable from the ratios for the Terre-Neuve samples. Sample R-142 exhibits an anomalously high initial ratio of 0.7084 . This sample is similar in both field occurrence and petrographic appearance to all of the other samples and we cannot account for its higher ratio at this time. 
TABLE 1

Present-day and initial ${ }^{87} \mathrm{Sr} /{ }^{86} \mathrm{Sr}$ ratio and concentration of $\mathrm{Rb}$ and $\mathrm{Sr}$ of Late Cretaceous granodiorites from the Greater Antilles

\begin{tabular}{llllll}
\hline Field No. & ${ }^{87} \mathrm{Sr} /{ }^{86} \mathrm{Sr} *$ & $\begin{array}{l}\mathrm{Rb} \\
(\mathrm{ppm})\end{array}$ & $\begin{array}{l}\mathrm{Sr} \\
(\mathrm{ppm})\end{array}$ & ${ }^{87} \mathrm{Rb} /{ }^{86} \mathrm{Sr}$ & $\left({ }^{87} \mathrm{Sr} /{ }^{86} \mathrm{Sr}\right)_{0}{ }^{* *}$ \\
\hline
\end{tabular}

Terre-Neuve intrusion, Haiti (assumed age, 66 m.y.)

$\begin{array}{lccccc}\text { M-150-EQM } & 0.7040 & 127 & 463 & 0.794 & 0.7028 \\ \text { M-1 (LQM) } & 0.7031 & 119 & 604 & 0.567 & 0.7026 \\ \text { M-2 (LQM) } & 0.7043 & 114 & 533 & 0.619 & 0.7037 \\ \text { M-61 } & 0.7048 & 125 & 640 & 0.546 & 0.7043 \\ \text { M-94 } & 0.7038 & 74.0 & 719 & 0.298 & 0.7035 \\ \text { SK-6 } & 0.7053 & 126 & 573 & 0.634 & 0.7047 \\ \text { SK-10 } & 0.7041 & 129 & 595 & 0.625 & 0.7035\end{array}$

Above Rocks intrusion, Jamaica (assumed age, $63 \mathrm{m.y.)}$

$\begin{array}{llllll}\text { R-77A } & 0.7035 & 44.6 & 877 & 0.147 & 0.7034 \\ \text { R-142 } & 0.7088 & 11.6 & 705 & 0.0476 & 0.7084 \\ \text { R-213 } & 0.7041 & 164 & 523 & 0.906 & 0.7033\end{array}$

* Present-day ratio; normalized to ${ }^{86} \mathrm{Sr} /{ }^{88} \mathrm{Sr}=0.1194$. Eimer and Amend interlaboratory $\mathrm{SrCO}_{3}$ standard, ${ }^{87} \mathrm{Sr} /{ }^{86} \mathrm{Sr}=$ $0.7079 \pm 0.0002(2 \sigma), N=15$.

$* * \lambda\left({ }^{87} \mathrm{Rb}\right)=1.42 \times 10^{-11} \mathrm{yr}^{-1}$.

The Above Rocks and Terre-Neuve intrusions contain a relatively high amount of potassium (Table 2). Because there is no continental sialic material to serve as a source for potassium, Donnelly et al. [11] suggested that this element has been incorporated from sea-floor sediments of continental origin into the magma rising from a melting process beneath the arc. The low initial ${ }^{87} \mathrm{Sr} /{ }^{86} \mathrm{Sr}$ ratios reported here for these rocks argue against this

\section{TABLE 2}

Concentrations of $\mathrm{Rb}$ and $\mathrm{K}_{2} \mathrm{O}$ for samples of granodiorites from Haiti and Jamaica

\begin{tabular}{llll}
\hline Field No. & $\begin{array}{l}\mathrm{Rb} \\
(\mathrm{ppm})\end{array}$ & $\begin{array}{l}\mathrm{K}_{2} \mathrm{O} * \\
(\%)\end{array}$ & $\mathrm{K} / \mathrm{Rb}$ \\
\hline
\end{tabular}

\begin{tabular}{lccc}
\hline \multicolumn{2}{l}{ Terre-Neuve intrusion, Haiti } & & \\
M-150-EQM & 127 & 3.6 & 240 \\
M-2 (LQM) & 114 & 3.7 & 250 \\
M-1 (LQM) & 119 & 2.8 & 200 \\
SK-6 & 126 & 2.7 & 180 \\
Above Rocks intrusion, Jamaica & & \\
R-77A & 44.6 & 1.3 & 240 \\
R-142 & 11.6 & 3.0 & 220 \\
R-213 & 164 & 4.8 & 240 \\
\hline
\end{tabular}

* $\mathrm{K}_{2} \mathrm{O}$ values from S.E. Kesler, XRF total-rock analyses. hypothesis. The rubidium content is also high in these rocks and it might be considered that there is a relationship between ${ }^{87} \mathrm{Sr} /{ }^{86} \mathrm{Sr}$ and $\mathrm{Rb} / \mathrm{Sr}$ ratios. Such is not the case, however, and in the Above Rocks complex variations in the $\mathrm{Rb} / \mathrm{Sr}$ appear to be related to crystal fractionation processes occurring during the differentiation of the magma, presumably at a high level in the crust. $\mathrm{K} / \mathrm{Rb}$ ratios are relatively low (Table 2), certainly much lower than average values for tholeiitic basalts in which the ratios are generally in the range of 1000 or greater [23], further suggesting that these trends are determined by crystal-liquid fractionation processes rather than by assimilation or contamination.

\section{Conclusions}

The results of this study indicate that a group of granodioritic intrusive rocks with initial ${ }^{87} \mathrm{Sr} /{ }^{86} \mathrm{Sr}$ ratios less than 0.704 were emplaced about 60 m.y. ago. The significance of this data is two-fold. First, these rocks contrast greatly with other intrusive rocks for which similar low initial ${ }^{87} \mathrm{Sr} /{ }^{86} \mathrm{Sr}$ ratios have been obtained. In studies of the Sierra Nevada, for example, Kistler and Peterman [24] have shown that the intrusive rocks with the low initial ratios in this 
complex are trondjhemites and tonalites with markedly lower $\mathrm{K}_{2} \mathrm{O}$ abundances than the Greater Antillean granodiorites. Thus, relatively potassic-rich rocks can apparently develop in oceanic island arcs as well as in continental settings. Secondly, it follows that these high- $\mathrm{K}_{2} \mathrm{O}$ intrusions must be accounted for in any model proposed for the generation of island arc magmas. Our data constrain such models in that the low initial ${ }^{87} \mathrm{Sr} /{ }^{86} \mathrm{Sr}$ ratios and low concentrations of strontium place relatively low limits on the amount of oceanic sediment (which would have a higher ${ }^{87} \mathrm{Sr} /{ }^{86} \mathrm{Sr}$ ratio) that can be incorporated into the magma. It appears, instead, that these granodiorites were derived in large part from melting of downthrust oceanic crust or adjacent mantle material.

\section{Acknowledgements}

The mass spectrometric measurements were made in the Analytical Chemistry Division of the Oak Ridge National Laboratory, which is operated for the U.S. Department of Energy by Union Carbide Corporation. Chemical isolation of the strontium and the analyses of rubidium and strontium were made by Lois M. Jones while associated with the University of Georgia, Athens. We gratefully acknowledge the assistance of Pam Randall of Continental Oil Company during the final preparation of the manuscript.

\section{Appendix}

Sample localities of two intrusions of granodiorite and associated rocks from Jamaica and Haiti, Greater Antilles

\section{Terre-Neuve intrusion, Haiti}

M-150-EQM. Granodiorite, early phase of Terre-Neuve stock, $1980 \mathrm{~m}$ southeast of main mine adit, Memé.

M-1 (LQM). Quartz monzonite, composite sample of late phase of Terre-Neuve stock, $915 \mathrm{~m}$ sou theast of main mine adit, Memé.

M-2 (LQM). Quartz monzonite, late phase of Terre-Neuve stock, $915 \mathrm{~m}$ south-southeast of main mine adit, Memé.

M-61. Quartz monzonite, late phase of Terre-Neuve stock, $760 \mathrm{~m}$ southeast of main mine adit, Memé.

M-94. Quartz monzonite, $700 \mathrm{~m}$ south-southeast of main mine adit, Memé.

SK-6. Quartz monzonite, $730 \mathrm{~m}$ southeast of main mine adit, Memé.
SK-10. Granodiorite, $1220 \mathrm{~m}$ sou theast of main mine adit, Memé.

\section{Above Rocks intrusion, Jamaica}

R-77A. Quartz monzodiorite, Golden River, Zion Hill, Jamaica GR $5920 / 4345$.

R-142. Quartz monzodiorite, Golden River, Zion Hill, Jamaica GR 58800/43903.

R-213. Adamellite (quartz-monzonite), Cassava River, Jamaica GR 59403/44600.

\section{References}

1 J.F. Lewis and S.E. Kesler, Tonalites (quartz diorites) from the Cordillera Central, Dominican Republic; a relatively minor plutonic rock type in the greater Antilles and Nicaraguan Rise, EOS, Am. Geophys. Union Trans. 54 (1973) 490 (abstract).

2 C.O. Bowin, Geology of Central Dominican Republic: a case history of part of an island arc, in: Caribbean Geological Investigations, H.H. Hess, ed., Geol. Soc. Am. Mem. 98 (1966) 11.

3 J.D. Longshore and T.W. Donnelly, Chemical petrology of the Virgin Islands batholith, Trans. Fourth Caribbean Geol. Conf., Trinidad (1968) 221.

4 A.C. Palmer, Geology of the Moncion-Jarabacoa area, Dominican Republic, Ph.D. Dissertation, Princeton University, Princeton, N.J. (1963) $256 \mathrm{pp.}$

5 L.M.R. Rutten, The age of the quartz dioritic and granodioritic rocks of the West Indies, Geol. Mijnb. 1 (1939) 128.

6 A.H. Barabas, K-Ar dating of igneous events and porphyry copper mineralization in west central Puerto Rico, Geol. Soc. Am. Abstr. Progr. 3 (1971) 498 (abstract).

7 L.J. Chubb and K. Burke, Age of the Jamaican granodiorite, Geol. Mag. 100 (1963) 524.

8 W.B. Harland, A.G. Smith and B. Wilcox, eds., The Phanerozoic time-scale, Geol. Soc. London Q. J. 120 (1964) $458 \mathrm{pp}$.

9 S.E. Kesler, Petrology of the Terre-Neuve igneous province, northern Haiti, in: Caribbean Geophysical, Tectonic, and Petrologic studies, T.W. Donnelly, ed., Geol. Soc. Am. Mem. 130 (1971) 119.

10 K.M. Khudoley and A.A. Meyerhoff, Paleogeography and geological history of Greater Antilles, Geol. Soc. Am. Mem. 129 (1971) 199 pp.

11 T.W. Donnelly, J.J.W. Rogers, P. Pushkar and R.L. Armstrong, Chemical evolution of the igneous rocks of the eastern west Indies, in: Caribbean Geophysical, Tectonic and Petrologic Studies, Geol. Soc. Am. Mem. 130 (1971) 181.

12 J.F. Lewis and B.M. Gunn, Aspects of island arc evolution and magmatism in the Caribbean: Geochemistry of some West Indian plutonic and volcanic rocks, Six th 
Caribbean Geol. Conf., Caracas, Venezuela, Mem. (1972) 171.

13 J.D. Weaver, Utuado Pluton, Puerto Rico, Geol. Soc. Am. Bull. 69 (1958) 1125.

14 G. Faure and P.M. Hurley, The isotopic conposition of strontium in oceanic and continental basalts: applications to the origin of igneous rocks, J. Petrol. 4 (1963) 31.

15 R.L. Armstrong, A model for the evolution of strontium and lead isotopes in a dynamic earth, Rev. Geophys. 6 (1968) 175 .

16 I.S.E. Carmicheal, F.J. Turner and J. Verhoogen, Igneous Petrology (McGraw-Hill, New York, N.Y. 1974) 739 pp.

17 S.E. Church and G.R. Tilton, Lead and strontium isotopic studies in the Cascade Mountains: bearing on andesite genesis, Geol. Soc. Am. Bull. 84 (1973) 431.

18 B.R. Doe and J.S. Stacey, The application of lead isotopes to the problems of ore genesis and ore prospect evaluation: a review, in: Stable Isotopes as Applied to Problems of Ore Deposits, W.E. Hall, ed., Econ. Geol. 69 (1974) 757.
19 C.E. Hedge and J.F. Lewis, Isotopic composition of strontium in three basalt-andesite centers along the Lesser Antilles arc, Contrib. Mineral. Petrol. 32 (1971) 39.

$20 \mathrm{P}$. Pushkar, Strontium isotope ratios in volcanic rocks of three island arc areas, J. Geophys. Res. 73 (1968) 2701.

21 P. Pushkar, A.M. Stueber, J.F. Tomblin and G.M. Julian, Strontium isotopic ratios in volcanic rocks from $\mathrm{St}$. Vincent and St. Lucia, Lesser Antilles, J. Geophys. Res. 78 (1973) 1279

22 A.E. Cameron, W.H. Christie, H.W. McKown, W.T. Raney, Jr. and D.H. Smith, Analy tical mass spectrometry at Oak Ridge National Laboratory, Oak Ridge Natl. Lab. Rep. 4643 (1971) 67 pp.

23 P. Jakes and A.J.R. White, $\mathrm{K} / \mathrm{Rb}$ ratios of rocks from island arcs, Geochim. Cosmochim. Acta 34 (1970) 849.

24 R.W. Kistler and Z.E. Peterman, Variations in $\mathrm{Sr}, \mathrm{Rb}, \mathrm{K}$, $\mathrm{Na}$, and initial ${ }^{87} \mathrm{Sr} /{ }^{86} \mathrm{Sr}$ in Mesozoic granitic rocks and intruded wallrocks in central California, Geol. Soc. Am. Bull. 84 (1973) 3489. 